\title{
Catellicoccus marimammalium gen. nov., sp. nov., a novel Gram-positive, catalase-negative, coccus- shaped bacterium from porpoise and grey seal
}

\author{
Paul A. Lawson, ${ }^{1}$ Matthew D. Collins, ${ }^{2}$ Enevold Falsen ${ }^{3}$ \\ and Geoffrey Foster ${ }^{4}$ \\ ${ }^{1}$ Department of Botany and Microbiology, University of Oklahoma, Norman, OK 73019, USA \\ 254 Parkway, Crowthorne, Reading RG45 6EW, UK \\ ${ }^{3}$ Culture Collection, Department of Clinical Bacteriology, University of Göteborg, S-413 46 \\ Göteborg, Sweden \\ ${ }^{4}$ SAC Veterinary Services, Inverness IV2 4JZ, UK
}

Two strains of an unknown Gram-positive, catalase-negative, facultatively anaerobic, coccus-shaped bacterium, originating from a porpoise and a grey seal, were characterized using phenotypic, biochemical and molecular phylogenetic methods. Chemical studies revealed the presence of a cell-wall murein based on L-lysine (type L-Lys-Gly-D-Asp) and a DNA G + C content of $38 \mathrm{~mol} \%$. Comparative 16S rRNA gene sequencing showed that this unidentified coccus-shaped organism formed a hitherto unknown subline closely related to, albeit distinct from, a number of other catalase-negative genera which included Enterococcus, Melissococcus, Tetragenococcus and Vagococcus. Other known Gram-positive, catalase-negative taxa were more distantly related. Tree-branching considerations and sequence divergence values of $>6 \%$ with recognized taxa were indicative of this novel bacterium representing a separate genus. Based on phenotypic and phylogenetic evidence, it is proposed that this unknown bacterium, recovered from a porpoise and a grey seal, be classified as a novel genus and species, Catellicoccus marimammalium gen. nov., sp. nov. The type strain is $\mathrm{M} 35 / 04 / 3^{\top}\left(=\mathrm{CCUG} 49459^{\top}=\mathrm{CIP}\right.$ $\left.108575^{\top}\right)$.

The taxonomy of the Gram-positive, facultatively anaerobic, catalase-negative cocci has undergone major changes during the past 20 years or so (Facklam, 2002; Facklam \& Elliott, 1995). The most significant change has been the rapid growth in the number of recognized genera. Some of the new genera, such as Enterococcus and Lactococcus, were created due to taxonomic revision of existing genera (Schleifer \& KilpperBälz, 1984; Schleifer et al., 1985). However, the great majority of newly defined genera containing catalase-negative, coccus-shaped organisms have resulted from improved knowledge of the phylogeny of these organisms due to $16 \mathrm{~S}$ rRNA gene sequencing and the utility of this molecular tool to search for novel phylogenetic diversity (e.g. Aguirre \& Collins, 1992; Aguirre et al., 1993; Collins et al., 1989, 1992, 1997, 1999). Currently over 20 genera of Gram-positive, facultatively anaerobic, catalase-negative cocci are known and it is evident that much novel diversity remains to be

\footnotetext{
The GenBank/EMBL/DDBJ accession number for the 16S rRNA gene sequence of strain CCUG $49459^{\top}$ is AJ854484.

An extended neighbour-joining tree based on 16S rRNA gene sequences is available as supplementary material in IJSEM Online.
}

described. During the course of a study of taxonomically unusual Gram-positive bacteria from marine animals, we have characterized two coccus-shaped organisms which do not appear to conform to any presently defined genera. Based on both phenotypic and phylogenetic evidence, we propose yet another novel Gram-positive, catalase-negative genus and species.

Two bacterial isolates were recovered from the carcasses of a harbour porpoise (Phocoena phocoena) and a grey seal (Halichoerius grypus) which were found on the east and west coastlines of Scotland, respectively. Strain M35/04/3 ${ }^{\mathrm{T}}$ was recovered from the mesentery, kidney, pericardial fluid, peritoneal fluid and small intestine of a porpoise which had died of severe enteritis and peritonitis. Strain M271/94/1 was isolated from the small intestine of a grey seal which had been shot. The unidentified strains were cultured on Columbia blood agar base supplemented with $5 \%$ sheep blood at $37^{\circ} \mathrm{C}$, under capnophilic conditions. Organisms were biochemically characterized using the API Rapid ID 32 Strep and API 20Strep systems according to the manufacturer's instructions (bioMérieux). Lancefield serological grouping was determined by using the Streptex (Remell 
Europe) test system. The $\mathrm{G}+\mathrm{C}$ content of DNA of strain M35/04/3 ${ }^{\mathrm{T}}$ was determined by HPLC according to Mesbah et al. (1989). For phylogenetic analysis, $16 \mathrm{~S}$ rRNA genes were amplified by PCR and directly sequenced using a Taq dyedeoxy terminator cycle sequencing kit (Applied Biosystems) and an automatic DNA sequencer (model 373A; Applied Biosystems). The closest known relatives of the new isolates were determined by performing database searches. Closely related sequences were retrieved from EMBL and aligned with the newly determined sequences using the program SEQtools (Rasmussen, 2002). The resulting multiple sequence alignment had approximately 100 bases at the $5^{\prime}$ end of the rRNA omitted from further analysis, because of alignment uncertainties due to the highly variable region $\mathrm{V} 1$, using the program GeneDoc (Nicholas et al., 1997). A phylogenetic tree was reconstructed according to the neighbourjoining method (Saitou \& Nei, 1987) with the programs SEQtools and TreeView (Page, 1996), and the stability of the groupings was estimated by bootstrap analysis (1000 replications).

The unidentified isolates consisted of Gram-positive, coccusshaped cells in pairs and short chains. The organisms were facultatively anaerobic but grew better under elevated $\mathrm{CO}_{2}$ and were catalase-negative. They were unusual in failing to grow in the liquid media commonly used for facultatively anaerobic, Gram-positive, catalase-negative cocci, even when supplemented with horse serum [e.g. brain-heart infusion broth (Oxoid), Todd-Hewitt broth (Oxoid), nutrient broth (Oxoid), fastidious anaerobe broth (LabM)]. They were non-haemolytic on sheep-blood agar and gave positive reactions with Lancefield group D antisera. Using the API 20Strep system, both of the isolates produced acid from trehalose and gave positive reactions for arginine dihydrolase and leucine arylamidase. All other tests on the API 20Strep system were negative. Using the API Rapid ID 32 Strep system, the two unknown organisms were relatively unreactive, giving positive reactions for acid from trehalose and production of arginine dihydrolase. Strain M271/94/1 also gave positive reactions for glycyl tryptophan arylamidase and urease, whereas these enzymes were not detected in strain M35/04/3 ${ }^{\mathrm{T}}$. All other tests on the API Rapid ID 32Strep gallery were negative for both strains. An examination of the cell wall of strain $\mathrm{M} 35 / 04 / 3^{\mathrm{T}}$ revealed a murein based on L-lysine, type: L-Lys-Gly-D-Asp, variation A4 $\alpha$ (nomenclature of Schleifer \& Kandler, 1972). To investigate the phylogenetic position of the unknown bacterium, comparative $16 \mathrm{~S}$ rRNA gene sequence analyses were performed. Sequence library searches revealed that the unknown isolates were phylogenetically most closely associated with the lactic acid group of bacteria, particularly enterococci, vagococci, tetragenococci, Melissococcus plutonius and Trichococcus pasteurii (data not shown). The unknown bacterium formed a distinct subline amongst the Gram-positive, catalasenegative taxa (the full tree is available as Supplementary Fig. S1 in IJSEM Online). A tree constructed using the neighbour-joining method, with a reduced dataset for convenience, depicting the phylogenetic affinity of the unknown

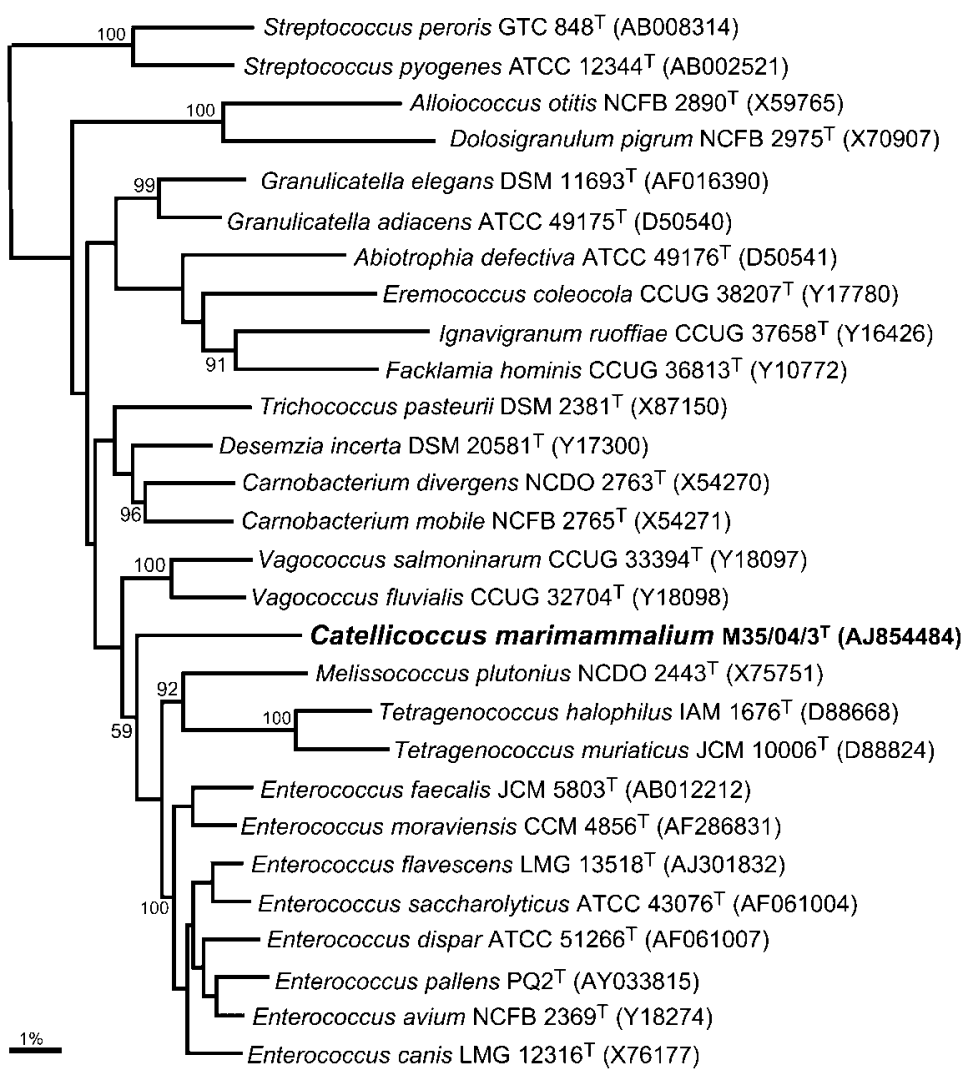

Fig. 1. Unrooted neighbour-joining tree based on $16 \mathrm{~S}$ rRNA gene sequences showing the phylogenetic relationships of Catellicoccus marimammalium gen. nov., sp. nov. Bar, $1 \%$ sequence divergence. An extended version of this tree is available as Supplementary Fig. S1 in IJSEM Online. 
coccus organism, as exemplified by strain $\mathrm{M} 35 / 04 / 3^{\mathrm{T}}$, is shown in Fig. 1. All the major groupings in the neighbourjoining tree were confirmed using the maximum-parsimony method (data not shown).

It is evident from both phenotypic and phylogenetic investigations that the two coccus-shaped strains, originating from a dead porpoise and a dead seal, represent a hitherto unrecognized bacterium within the low $\mathrm{G}+\mathrm{C}$ content, Grampositive, catalase-negative group of organisms. Phylogenetic analysis showed that the unidentified isolates represent a hitherto unknown species, closely related to, but distinct from, enterococci $(92 \cdot 6-93 \cdot 7 \%$ sequence similarity), vagococci $(91 \cdot 5-92 \cdot 6 \%$ sequence similarity), tetragenococci (89.4-90.4\% sequence similarity) and M. plutonius (92.1\% sequence similarity). The unknown bacterium formed a distinct subline which did not display a statistically significant association with any known taxon (Fig. 1) as evident from bootstrap resampling. Phenotypic data were consistent with the separateness of the unknown isolates. In particular, the presence of a murein type L-Lys-Gly-D-Asp in this unidentified bacterium is relatively rare within the Grampositive, catalase-negative group of organisms. To our knowledge amongst the close phylogenetic relatives of the unknown bacterium, this murein type has only been reported in Vagococcus salmoninarum (Wallbanks et al., 1990). However, the unknown bacterium differs markedly from the latter species in growing at $37^{\circ} \mathrm{C}$, producing arginine dihydrolase, not producing pyrrolidonyl arylamidase and failing to hydrolyse aesculin. Other close phylogenetic relatives of the unknown bacterium, such as enterococci (murein types L-Lys-D-Asp or L-Lys-D-Ala ${ }_{2-3}$ ) and Vagococcus fluvialis (L-Lys-D-Asp) contain different cell-wall peptidoglycans. In addition, the unidentified isolates differ significantly from vagococci and enterococci, in not growing in the liquid media commonly used for the cultivation of these organisms and by being pyrrolidonyl arylamidasenegative. These traits preclude the assignment of the unknown bacterium to these genera. M. plutonius also differs from these novel organisms from marine mammals in possessing a cell-wall murein type L-Lys-Ala ${ }_{n}$ (Bailey \& Collins, 1982). The latter species is also extremely fastidious and obligately anaerobic. Therefore, based on the results of the phylogenetic analysis and phenotypic evidence, we consider the novel bacterium from sea mammals merits classification in a new genus and species, for which the name Catellicoccus marimammalium gen. nov., sp. nov. is proposed.

\section{Description of Catellicoccus gen. nov.}

Catellicoccus (Ca.tel'li.coc' cus. L. fem. n. catella small chain; N.L. masc. n. coccus from Gr. masc. n. kokkos berry; N.L. masc. n. Catellicoccus coccus forming small chains).

Cells are Gram-positive, non-spore-forming and coccoid in shape. Cells are arranged in pairs or chains. Cells are nonmotile, facultatively anaerobic and catalase-negative. Do not grow in conventional laboratory liquid media with or without serum. No growth at $10{ }^{\circ} \mathrm{C}$. Grow in $10 \%$ bile. Some sugars are fermented. Arginine dihydrolase and leucine arylamidase are produced. Pyroglutamic acid arylamidase and alkaline phosphatase are not produced. Aesculin and hippurate are not hydrolysed. Nitrate is not reduced. VogesProskauer negative. Cell-wall murein is based on L-Lys-GlyD-Asp (type A4 $\alpha$ ). The type species is Catellicoccus marimammalium; the $\mathrm{G}+\mathrm{C}$ content of genomic DNA of the type species is $38 \mathrm{~mol} \%$.

\section{Description of Catellicoccus marimammalium sp. nov.}

Catellicoccus marimammalium (ma'ri.mam.ma'li.um. L. neut. $\mathrm{n}$ mare the sea; N.L. neut. gen. pl. n. mammalium of mammals; N.L. gen. pl. n. marimammalium of marine mammals).

Displays the following properties in addition to those given in the genus description. Colonies are non-haemolytic, semitranslucent, round, entire, $0 \cdot 25-0.55 \mathrm{~mm}$ in diameter after $24 \mathrm{~h}$ growth on blood agar. Growth is enhanced in $\mathrm{CO}_{2}$. Reacts with Lancefield group D antisera. Acid is produced from trehalose but not from L-arabinose, D-arabitol, cyclodextrin, glycogen, inulin, lactose, maltose, mannitol, melibiose, melezitose, methyl $\beta$-D-glucopyranoside, pullulan, raffinose, ribose, sorbitol, starch, sucrose or tagatose. Alanine phenylalanine proline arylamidase, $\alpha$-galactosidase, $\beta$-galactosidase, $\beta$-glucosidase, $\beta$-glucuronidase, $N$-acetyl$\beta$-glucosaminidase and $\beta$-mannosidase are not produced. Glycyl tryptophan arylamidase and urease may or may not be detected.

The type strain is $\mathrm{M} 35 / 04 / 3^{\mathrm{T}} \quad\left(=\mathrm{CCUG} 49459^{\mathrm{T}}=\mathrm{CIP}\right.$ $108575^{\mathrm{T}}$ ), isolated from a porpoise (Phocoena phocoena) which had died of severe enteritis and peritonitis, found on the east coastline of Scotland.

\section{Acknowledgements}

We are grateful to Hans Trüper of the University of Bonn for help in coining the genus name. We also acknowledge Bob Reid, Harry Ross and Tony Patterson of SAC Veterinary Services, Inverness. The Scottish Strandings Scheme receives financial support from the UK Department of the Environment, Farming and Rural Affairs.

\section{References}

Aguirre, M. \& Collins, M. D. (1992). Phylogenetic analysis of Alloiococcus otitis gen. nov., sp. nov., an organism from human middle ear fluid. Int J Syst Bacteriol 42, 79-83.

Aguirre, M., Morrison, D., Cookson, B. D., Gay, F. W. \& Collins, M. D. (1993). Phenotypic and phylogenetic characterisation of some Gemella-like organisms from human infections: description of Dolosigranulum pigrum gen. nov., sp. nov. J Appl Bacteriol 75, 608-612.

Bailey, L. \& Collins, M. D. (1982). Reclassification of Streptococcus pluton (White) in a new genus Melissococcus, as Melissococcus pluton nom. rev.; comb. nov. J Appl Bacteriol 53, 215-217.

Collins, M. D., Ash, C., Farrow, J. A. E., Wallbanks, S. \& Williams, A. M. (1989). 16S Ribosomal ribonucleic acid sequence analyses of 
lactococci and related taxa. Description of Vagococcus fluvialis gen. nov., sp. nov. J Appl Bacteriol 67, 453-460.

Collins, M. D., Aguirre, M., Facklam, R. R., Shallcross, J. \& Williams, A. M. (1992). Globicatella sanguis gen. nov., sp. nov., a new grampositive catalase. negative bacterium from human sources. J Appl Bacteriol 73, 433-437.

Collins, M. D., Falsen, E., Lemozy, J., Åkervall, E., Sjödén, B. \& Lawson, P. A. (1997). Phenotypic and phylogenetic characterization of some Globicatella-like organisms from human sources: description of Facklamia hominis gen. nov., sp. nov. Int J Syst Bacteriol 47, 880-882.

Collins, M. D., Lawson, P. A., Monasterio, R., Falsen, E., Sjödén, B. \& Facklam, R. R. (1999). Ignavigranum ruoffiae sp. nov., isolated from human clinical specimens. Int J Syst Bacteriol 49, 97-101.

Facklam, R. R. (2002). What happened to the streptococci: overview of taxonomic and nomenclature changes. Clin Microbiol Rev 15, 613-630.

Facklam, R. R. \& Elliott, J. A. (1995). Identification, classification, and clinical relevance of catalase-negative, gram-positive cocci, excluding the streptococci and enterococci. Clin Microbiol Rev 8, 479-495.

Mesbah, M., Premachandran, U. \& Whitman, W. B. (1989). Precise measurement of the $\mathrm{G}+\mathrm{C}$ content of deoxyribonucleic acid by highperformance liquid chromatography. Int J Syst Bacteriol 39, 159-167.

Nicholas, K. B., Nicholas, H. B., Jr \& Deerfield, D. W., II (1997). GeneDoc: analysis and visualization of genetic variation. EMBNEW News 4, 14.

Page, R. D. M. (1996). TreeView: an application to display phylogenetic trees on personal computers. Comput Appl Biosci 12, 357-358.
Pot, B., Vandamme, P. \& Kersters, K. (1994). Analysis of electrophoretic whole-organism protein fingerprints. In Modern Microbial Methods. Chemical Methods in Prokaryotic Systematics, pp. 493-521. Edited by M. Goodfellow \& A. G. O’Donnell. Chichester: Wiley.

Rasmussen, S. W. (2002). SEQtools, a win32 software suite for analysis and handling of nucleotide and protein sequences. http:// www.seqtools.dk

Saitou, N. \& Nei, M. (1987). The neighbor-joining method: a new method for reconstructing phylogenetic trees. Mol Biol Evol 4, 406-425.

Schleifer, K. H. \& Kandler, O. (1972). Peptidoglycan types of bacterial cell walls and their taxonomic implications. Bacteriol Rev 36, 407-477.

Schleifer, K. H. \& Kilpper-Bälz, R. (1984). Transfer of Streptococcus faecalis and Steptococcus faecium to the genus Enterococcus nom. rev. as Enterococcus faecalis comb. nov. and Enterococcus faecium comb. nov. Int J Syst Bacteriol 34, 31-34.

Schleifer, K. H., Kraus, J., Dvorak, C., Kilpper-Balz, R., Collins, M. D. \& Fischer, W. (1985). Transfer of Streptococcus lactis and related streptococci to the genus Lactococcus gen. nov. Syst Appl Microbiol 6, 183-195.

Vandamme, P., Torck, U., Falsen, E., Pot, B., Goossens, H. \& Kersters, K. (1998). Whole-cell protein electrophoretic analysis of viridans Streptococcus mitis biovars. Int J Syst Bacteriol 48, 117-125.

Wallbanks, S., Martinez-Murcia, A. J., Fryer, J. L., Philips, B. A. \& Collins, M. D. (1990). $16 \mathrm{~S}$ rRNA sequence determination for members of the genus Carnobacterium and related lactic acid bacteria and description of Vagococcus salmoninarum sp. nov. Int J Syst Bacteriol 40, 224-230. 